DOI: https://doi.org/10.31874/2309-1606-2020-26-2-9

УДК 17.02:17.02

\title{
Катерина Рассудіна
}

\section{Етичний кодекс лікаря: виховання гідності}

Виховання - частина освітнього процесу, яка формує в людині вміння відчувати гідність

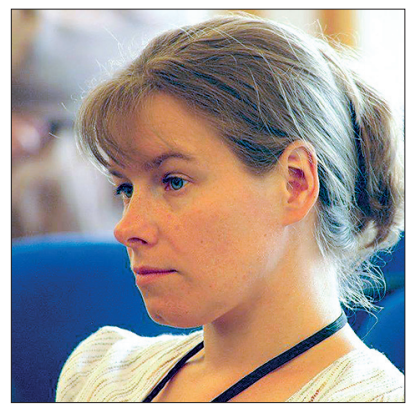
у ній самій та інших. Таке вміння має особливе значення для медичного працівника, покликання якого вимагає від нього чуйності до пацієнта. Перебуваючи у стані хвороби, людина гостро переживає «втрату гідності». Отож, одне з завдань лікаря полягає у тому, щоби побачити гідність свого пацієнта, розпізнати ті їі регіони, які є ураженими, $i$ правильно вшанувати непорушне осердя цієї гідності. Авторка статті подає дороговказ для такого розрізнення, для чого досліджує чотири варіанти класифікації типів гідності, визначає найголовніший із них і демонструє ситуації з медичної практики, в яких актуалізується потреба в цьому розрізненні.

Під гідністю авторка має на увазі багатоаспектний феномен, який відповідає, водночас, непорушній цінності людської особи, доброчесності, статусу морального суб'єкта. Така багатоаспектність відображається у спробах типологізації гідності. У статті наведено концепції розрізнення типів гідності, запропоновані Л. Р. Касом (базова гідність людського буття і повна гідність буття людиною), В. Князевичем (онтологічний і екзистенційний аспекти), А. Роджіньскім (особистісна, особиста й особова гідність), Д. П. Салмесі (атрибутивна, розквітла і внутрішня гідність).

Хвороба, особливо поважна, являє собою випробування для гідності. Авторка, однак, доводить, що базовий шар гідності залишається непорушним навіть тоді, коли людина перебуває у станах, які не відповідають статусу раціональної істоти. Стверджується, що хвороба завдає ударів менш суттєвим шарам гідності. Покликання лікаря, отож, полягає у тому, щоби, по-перше, розпізнати ці ушкоджені аспекти, а по-друге, продемонструвати пацієнту той факт, що його базова, внутрішня, особова чи онтологічна гідність не може бути втраченою за жодних обставин. Виховання у майбутніх лікарів уміння розрізняти всі аспекти гідності має бути важливим моментом освітнього процесу медичних навчальних закладів.

Ключові слова: гідність, багатоаспектність, хвороба, покликання лікаря, виховання.

(C) Г. Губенко, 2021 
Важливою складовою освітнього процесу є виховання. Якщо завдяки навчанню ми прагнемо отримати доброго спеціаліста у певній галузі, або ж суб'єкта навичок, які допоможуть йому орієнтуватися в різних життєвих ситуаціях, спілкуватися з людьми, заробляти гроші, то виховання покликане, насамперед, до прищеплення моделей поведінки, орієнтованої на вшанування людської гідності. Таке виховання $\epsilon$ необхідним усюди, а особливо там, де надають освіту фахівцям, які працюватимуть з людьми, що перебувають у певній скруті, чия гідність здається приниженою і непомітною, тобто лікарям. Згідно з «Етичним кодексом лікаря України», «Лікар виконує свої обов'язки з повагою до життя, гідності і особистості кожного пацієнта» [ЕКЛУ 2009: 7], а водночас «повинен бути гідним прикладом для своїх колег та інших членів суспільства» [ЕКЛУ 2009: 7]. Відповідно, важливим елементом підготовки лікарів $є$ розвиток у них здатності розпізнавати справжню гідність під нашаруванням поверхових інтерпретацій.

Для виховання гідності науковці розробляють особливі рекомендації, враховуючи психологічні, культурні, релігійні особливості різних груп населення. Зокрема, існують праці, присвячені вихованню почуття гідності у лікарів. Їхніми авторами $\epsilon$ Р. Дресер Л. Р. Кас, Е. Д. Пелегріно, Д. П. Салмесі та ін. Нашою метою $є$ розкриття тих аспектів гідності, розуміння яких $\epsilon$ необхідним елементом освіти майбутніх медиків, покликаних шанувати гідність пацієнта під час їхньої праці. Для цього ми виконаємо такі завдання: 1) надамо визначення гідності, релевантне уявленням сучасного українця; 2) наведемо чотири класифікації типів гідності, що допоможе нам зрозуміти гідність як складний багатоаспектний феномен; 3) визначимо тип гідності, повагу до якої має розвивати у собі лікар; 4) продемонструємо, як виховання гідності може виявлятися у медичній практиці.

\section{Чим є гідність}

Насамперед, потрібно визначитися із тим, що ми маємо на увазі під гідністю. Зауважмо при цьому, що йдеться про феномен, який важко редукувати до якогось іншого феномена, хоча, безсумнівно, досвід переживання гідності, iї пошанування й приниження має кожен із нас. Цей наш досвід, часто негативний, якщо піддати його рефлексії, підказує нам, що гідність - це особлива цінність, притаманна людській особі. Властиве сучасності множення і релятивізація цінностей ускладнює схоплення гідності. Тож освітній процес може стати тим майданчиком, на якому молоді люди отримують навички розрізнення між головним і другорядним, партикулярним та універсальним, не втрачаючи такої 
важливої цінності, як сама свобода вибору, але піднімаючи її на рівень свободи порівняння та оцінки [Йосипенко 2020: 80].

Освіта, вводячи певну особу в її майбутній фах, дарує їй набагато більше, виховує. «Сенс освіти у розвитку людини, - пише Є. Мулярчук, - в сприянні її самовизначенню і усвідомленню їі життєвої мети, тобто у формуванні розуміння та здатності до вибору особистісного і суспільного блага, яке вона бажає реалізувати у світі» [Мулярчук 2019: 190]. Ідеться про пошук, визначення і вірність покликанню. Для лікарів, покликання яких стосується допомоги людям у момент їхньої слабкості, крихкості, вразливості, стає важливим вміння пробитися крізь нашарування різних значень до осердя цінності людини і зрозуміти його правильно.

Тривалий досвід філософської рефлексії над природою цінностей взагалі і цінності самої людської особи зокрема, демонструє, що остання, тобто гідність, є складним феноменом, який важко розпізнати і легко сплутати з чимось, чим вона не $\epsilon$, або звести до лише одного з їі аспектів. Такої помилки, здається, припустилася Р. Меклін, коли прирівняла гідність до автономії, а повагу до неї - до визнання лише цінності індивідуальних переконань [Macklin 2003: 1419-1420]. 3 іншого боку, складність розуміння гідності обумовлена змінністю цього концепту не тільки з плином часу, але й у різних культурах.

Утім, нам ідеться про те, що кожна людина (а особливо лікар, покликання якого становить турбота про гідність) в процесі свого виховання все ж має - і здатна - навчитися розпізнавати гідність особи, а тому ми мусимо бодай підступитися до визначення цього поняття, принаймні, в такому вигляді, як воно сформувалося в західноєвропейській цивілізації. Колектив українських біоетиків запропонував перелік дефініцій гідності, які узгоджуються з цим цивілізаційним баченням. По-перше, гідність ми ототожнюємо з певною чеснотою, яка формується в спільноті і відповідає соціальному статусу; по-друге - зі згодою про певні кордони, які не можуть бути порушеними; по-третє, з обмеженням соціально неприйнятної поведінки (тут носій гідності трактується як суб'єкт моралі); по-четверте, з відкритістю до метафізичних вимірів життя [Пустовіт et al. 2012: 135].

\section{Розмаїття гідностей}

Як бачимо, дослідники гідності розкривають досить широке віяло їі значень. Цей факт не стане перешкодою для пізнання і виховання гідності, якщо припустити, що вона являє собою багатошарове явище. Дослідники вказують, принаймні, на два типи притаманної кожній людині гідності. Так, американський лікар і філософ Л. Р. Кас розрізняє базову 
гідність людського буття (basic dignity of human being) і повну гідність буття людиною (full dignity of being human). Перша з них належить кожній людині, навіть якщо та не виявляє її назовні, становить підставу для рівних прав, рівної цінності самого людського життя. На думку Л. Р. Каса, про неї свідчить «наша майже природна здатність розпізнавати humanum в іншому» [Kass 2008: 319]. Натомість повна гідність буття людиною залежить від реалізації тих можливостей, які закладені в кожному з нас, а тому приписування ії еонкретним особам буде різнитися в залежності від того, чи приклали вони зусиль для того, щоби реалізувати всі доступні їм духовні починання.

Український дослідник В. Князевич також пише про два аспекти гідності - онтологічний та екзистенційний. У першому випадку ідеться про здатність до самостійних рішень і дій, це «елементи, які грунтуються в бутті та природі людської особи без огляду на будь-які свідомі та інтенціональні акти, які особа може здійснювати» [Князевич 2016: 28]. Екзистенційний аспект гідності пов'язаний з реалізацією окреслених вище здатностей, залежить від свідомого життя особи.

Інші класифікації типів гідності, враховують три її визначення, шари або регіони. Спочатку наведемо пропозицію польського філософа А. Роджіньского, який ще 1968 р. розрізнив три типи гідності - особистісну (osobowościowa), особисту (osobista) і особову (osobowa) [Rodziński 1968: 43-49]. В першому випадку він мав на увазі ті набуті риси, які характеризують моральний, психічний, фізичний стан, є плинними, своєрідними для кожної людини. Таку гідність ми можемо покращити чи втратити в очах інших. Особисту гідність дослідник ототожнює з почуттям власної цінності, тобто вона $є$ суб'єктивною, залежить від тих переживань, які часто $\epsilon$ прихованим чинником людських дій, не завжди співпадає 3 об'єктивною оцінкою заслуг певного індивіда, змінюється аж до зникнення. Нарешті, найглибший тип гідності - особова - належить особі як такій, кожному, кого ми називаємо кимось, а не чимось. Тільки така гідність не залежить від людських суджень - власних і сторонніх, вона пов'язана із самим фактом нашого існування, $\epsilon$ невід'ємною.

Варто звернути увагу також на міркування американського дослідника Д. П. Салмесі, який, подібно до А. Роджіньского, розрізнює три типи гідності, хоча в дещо іншій перспективі. Відповідно, він пише про атрибутивну (attributed), розквітлу (inflorescent) і внутрішню (intrinsic) гідність. Дуже зручно уявити їх у вигляді шарів, де перший лежатиме на поверхні, а останній буде найбільш прихованим. Атрибутивна гідність, за самим визначенням, надається особі ззовні - за певні заслуги, внески у розбудову спільноти, і асоціюється з винагородою, як грошовою, так і у вигляді надання відзнак, привілеїв, високого соціального статусу [Sul- 
masy 2008: 471, 480]. Такого типу гідність не $є$ вродженою, різні люди не володіють нею рівною мірою.

Розквітла гідність, так само, як атрибутивна, набувається особою в процесі життя, утім, завдяки внескам іншого роду - розвитку людської досконалості. Передовсім, ідеться про плекання чеснот, моральних якостей, інтелектуальних здібностей [Sulmasy 2008: 473]. Якщо в першому випадку вшановується праця на благо певного колективу, то в другому - талант і доброчесність. 3 іншого боку, ми немовби передбачаємо існування в людині розквітлої гідності ще до її остаточного виявлення, коли очікуємо від неї відповідної «людської» поведінки.

Внутрішня гідність, найглибший, а водночас, найголовніший, справжній ïï шар, є вродженою і невід'ємною. Це аналог особової гідності з класифікації А. Роджіньского. Вона $є$ безумовною, але заслуговує на повагу вже тому, що належить раціональній істоті, homo sapiens. Це завдяки їй людина не може бути лише засобом, а завжди являє собою і ціль. «Під внутрішньою гідністю,- пише Д. П. Салмесі, - я маю на увазі ту вартість чи цінність, яку люди посідають просто тому, що $€$ людьми, не завдяки якомусь соціальному становищу, здатності викликати захват, або ж окремому набору талантів, навичок чи здібностей» [Sulmasy 2008: 473].

Наведені вище способи класифікації шарів гідності служать нам підказкою у тому, що одним з найбільших задач вихователя $є$ розвиток у підопічному (чи собі самому) вміння «вчуватися» в іншу особу (і власну душу) так, щоби розрізняти у ній різні аспекти гідності. А також, що не менш важливо, надавати перевагу вшануванню базової гідності людського буття (за Л. Р. Касом), онтологічної (за В. Князевичем), особової (за А. Роджіньскім), внутрішньої (за Д. П. Салмесі). В певному сенсі йдеться про виховання мудреця. «Добре вихована людина, - пише 3 цього приводу В. Худий, - це, отож, хтось, здатний відкрити важливе в людині і для людини, а також чинити згідно з цим особливим знанням; це, власне, мудра людина» [Chudy 2009: 57]. Пізнання людської гідності, мудрість, вимагає не лише теоретичної, але й практичної діяльності, яка полягає у безкорисливому прийнятті іншого.

\section{Покликання лікаря}

Яким чином окреслена настанова виявляється у медичній практиці? Для того, щоби відповісти на це питання, потрібно, по-перше, подивитися на стан хворої людини крізь призму класифікації їі гідності. Варто пам'ятати, що внутрішня, базова, особова чи онтологічна гідність не руйнуються жодною хворобою, навіть такою, яка заважає пацієнту досягати поставлених нею цілей, збільшувати суспільне благо, в цілому 
виявляти ті якості, які характеризують людину. Певні удари завдаються іншим типам гідності. Можна сказати, що захворювання, які деформують інтелектуальні спроможності людини, або ж поважно обмежують її фізично, шкодять розквітлій гідності. У термінах А. Роджіньского, безперечно, йдеться про удар по особистій гідності, пов'язаний з низькою самооцінкою людей, які зазнали втрати своїх властивостей. Атрибутивна чи особистісна гідність страждає внаслідок того, що хворий втрачає свій суспільний статус.

Отож, пошанування гідності, чеснота, яку має плекати у собі лікар, полягає у тому, щоб пам'ятати про глибоко приховану внутрішню гідність і не зосереджуватися на її менш суттєвих аспектах, пам'ятати про те, що «природна й онтологічна гідність грунтується не на фізичному чи матеріальному благополуччі, а передусім на духовності людини» [Терешкевич et al. 2016: 26].

Уміння вчуватися в переживання пацієнта, розпізнавати рани, завдані його атрибутивній, розквітлій, особистій, особистісній чи повній гідності, а також неушкоджену внутрішню гідність, демонструє лікар і філософ Е. Д. Пелегріно. Сама вразливість хворого свідчить про руйнацію верхніх шарів його гідності, викликану, передовсім, його залежністю від інших. Покликання лікаря полягає у тому, щоби усіма своїми вчинками, відсутністю зверхності, уважністю до потреб і вибору пацієнта оживити в ньому пригноблене відчуття вродженої гідності [Pellegrino 2008: 522-523].

Ушкодження атрибутивної чи особистісної гідності може виявлятися як відчуття провини за власну слабкість, коли хвороба змушує людину відступити на довший чи коротший час від повсякденних обов'язків i, навпаки, стати тягарем для своєї спільноти. Особливо прикметним такий стан $є$ нині, коли «гонитва за здоров'ям стала чимось на кшталт культу» і «може здаватися, що, стаючи слабкими, ми зазнаємо невдачі» [Pellegrino 2008: 523]. Відчуття втрати гідності, виражене як сором, викликає публічність, яку передбачають медичні огляди, контроль над пацієнтом, лікарняна рутина, відстороненість персоналу, або ж патерналізм, заборона висловлювати власну думку щодо терапевтичних процедур тощо. Е. Д. Пелегріно постулює необхідність впроваджувати ліберальну модель стосунків між лікарем і пацієнтом.

Е. Д. Пелегріно звертає увагу і на той факт, що гідність мають навіть ті пацієнти, які, як може здатися, втрачають, або ж зовсім не набувають іï з огляду на свій вік (немовлята), або стан (кома, деменція). «Концепція гідності, під якою я підписуюся, - заявляє американський філософ, - присвоює невід'ємну природжену гідність усім людям просто тому, що вони є тими істотами, якими є. Жоден патофізіологічний механізм, який порушує здатність людини до свідомого досвіду, не може змінити гід- 
ності. Патофізіологічні відхилення свідомості перебувають у сфері приписуваної або атрибутивної гідності; вони не стосуються внутрішньої або вродженої гідності» [Pellegrino 2008: 528].

\section{Висновки}

На прикладі практичного досвіду Е. Д. Пелегріно ми бачимо ту значущість, яку має для лікаря виховання гідності. Ідеться, врешті решт, не тільки про те, щоби розпізнати у пацієнті особу з невід'ємною гідністю, верхні шари якої ушкоджено, що викликає психічні страждання, іноді більші ніж фізичний біль. Ідеться про виховання медичним працівником його власної гідності - розпізнання тих учинків, мотивів, прагнень, які, насправді, служать звеличенню її атрибутивного чи, може, особистого аспекту, а не розквітлого, з яким пов'язані справжні чесноти лікаря - чутливість і милосердя.

\section{Посилання:}

Етичний кодекс лікаря України (2009). Медицина транспорту України 4, 6-11.

Йосипенко, С. (2020). Освіта і ситуація множинності цінностей. Філософія освіти, 26(1), 68-83.

Князевич, В. (2016). Гідність - осердя людської особи. Шостий національний конгрес з біоетики, 27-30 вересня 2016: матеріали наук. конф. за міжнар. участі. Київ, 28.

Мулярчук, Є. (2019). Покликання людини у сучасному світі: відповідальність та очікувані компетенції педагогів. Філософія освіти, 24(1), 187-200.

Пустовіт, С., Кулініченко, В., \& Палєй, Л. (2012). Концептуальні засади глобальної біоетики. Практична філософія, (2), 131-138.

Терешкевич, Г., Голубець, О., Шуст, О., \& Оліферчук В. (2016). Креаціонізм і персоналізм як теоретичне підгрунтя біоетики. Шостий національний конгрес з біоетики, 27-30 вересня 2016: матеріали наук. конф. за міжнар. участі. Київ, 25-26.

Chudy, W. (2009). Pedagogia godności: Elementy etyki pedagogicznej. Lublin: TN KUL.

Kass, L. R. (2008). Defending Human Dignity. Schulmanand, A. et al. (ed.). Human Dignity and Bioethics. Essays Commissioned by the President's Council on Bioethics. Washington, D.C.: President's Council on Bioethics, 297-330.

Macklin, R. (2003). Dignity is a useless concept. British Medical Journal, 327, 1419-1420. https://www.ncbi.nlm.nih.gov/pmc/articles/PMC300789/.

Pellegrino, E.D. (2008). The Lived Experience of Human Dignity. Schulmanand, A. et al. (ed.). Human Dignity and Bioethics. Essays Commissioned by the President's Council on Bioethics. Washington, D.C.: President's Council on Bioethics, 513-539.

Rodziński, A. (1968). U podstaw kultury moralnej. O genezie i podstawowej strukturze wartości moralnej naturalnej i wartosciowania ściśle moralnego. Roczniki filozoficzne, $16(2), 43-49$.

Sulmasy, D. P. (2008). Dignity and Bioethics: History, Theory, and Selected Applications. In: Human Dignity and Bioethics. Essays Commissioned by the President's Council on Bioethics (ed. A. Schulmanand others). Washington, D.C.: President's Council on Bioethics, 469-501. 


\section{References:}

Chudy, W. (2009). Pedagogy of dignity: Elements of pedagogical ethics. Lublin: TN KUL. [In Polish].

Code of Ethics of the Doctor of Ukraine (2009). Transport Medicine of Ukraine 4, 6-11. [In Ukrainian].

Yosypenko, S. (2020). Education and situation of the plurality of values. Philosophy of Education 26(1), 68-83. [In Ukrainian].

Kass, L. R. (2008). Defending Human Dignity. Schulmanand, A. et al. (ed.). Human Dignity and Bioethics. Essays Commisioned by the President's Council on Bioethics. Washington, D.C.: President's Council on Bioethics, 297-330.

Kniazevych, V. (2016). Dignity is the core of human person. Sixth National Congress on Bioethics, September 27-30, 2016: materials of the scientificconf. with internat. part. Kyiv, 28. [In Ukrainian]

Macklin, R. (2003). Dignity is a useless concept. British Medical Journal, 327, 1419-1420. https://www.ncbi.nlm.nih.gov/pmc/articles/PMC300789/.

Muliarchuk, Ye. (2019). Human calling in the contemporary world: responsibility and expected competencies of educators. Philosophy of Education, 24(1), 187-200. [In Ukrainian].

Pellegrino, E.D. (2008). The Lived Experience of Human Dignity. Schulmanand, A. et al. (ed.). Human Dignity and Bioethics. Essays Commissioned by the President's Council on Bioethics. Washington, D.C.: President's Council on Bioethics, 513-539.

Pustovit, S., Kulinichenko, V., \& Paliei, L. (2012).Conceptual principles of global bioethics. Practical philosophy, (2), 131-138. [In Ukrainian].

Rodziński, A. (1968).At the core of moral culture. On genesis and basic structure of natural moral value and strictly moral evaluation. Philosophical annals, 16(2), 43-49. [In Polish].

Sulmasy, D. P. (2008). Dignity and Bioethics: History, Theory, and Selected Applications. In: Human Dignity and Bioethics. Essays Commissioned by the President's Council on Bioethics(ed. A. Schulmanand others). Washington, D.C.: President's Council on Bioethics, 469-501.

Tereshkevych, H., Holubets, O., Shust O., \& Oliferchuk, V. (2016). Creationism and personalism as a theoretical basis of bioethics. Sixth National Congress on Bioethics, September 27-30, 2016: materials of the scientific conf. with internat. part. Kyiv, 25-26. [In Ukrainian].

\section{Kateryna Rassudina. Physician's Code of Ethics: Education of Dignity}

Education is a part of the educational process that forms a person's ability to feel dignity in himself and in others. Such a skill is of particular importance to the healthcare professional, whose vocation requires sensitivity to the patient. In a state of disease, a person acutely experiences a "loss of dignity". So, one of the tasks of a physician is to see the dignity of his patient, to recognize its regions that are injured, and to pay proper respect to the inviolable core of the dignity. The author of the article provides guidelines for such a distinction. She researches the types of dignity, identifies the most important of them, and demonstrates situations in medical practice in which this distinction is relevant. 
The author understands dignity as a multifaceted phenomenon which corresponds to the inviolable value of the human person, virtue, the status of a moral subject. Such multifacetedness is reflected in attempts to typologize dignity. The article presents the concepts of distinguishing types of dignity proposed by L. R. Kass (basic dignity of human being and full dignity of being human), V. Kniazevich (ontological and existential aspects), A. Rodziński (dignity of personality, personal dignity and dignity of the person), D. P. Sulmasy (attributed, inflorescent and intrinsic dignity).

The disease, especially the serious one, is a test of dignity. The author, however, argues, that the basic layer of dignity remains inviolable even in states that do not correspond to the status of a rational being. It is claimed that the disease injures less significant layers of dignity. The physician's vocation, therefore, is to recognize these injured aspects and to demonstrate to the patient the fact that his basic, intrinsic, ontological dignity cannot be lost under any circumstances. Educating future physicians to be able to distinguish between all aspects of dignity should be an important part of the educational process in medical schools. tion.

Key words: dignity, multifacetedness, disease, vocation of the physician, educa-

Катерина Рассудіна - кандидат філософських наук, докторант кафедри теоретичної і практичної філософії Київського національного університету імені Тараса Шевченка; вчений секретар Інституту релігійних наук св. Томи Аквінського в Києві.

e-mail: rassudina.k@gmail.com

https://orcid.org/0000-0000-0001-6704-185X

Kateryna Rassudina - PhD, postdoctoral researcher of Department of Theoretical and Practical Philosophy at Taras Shevchenko National University of Kyiv; scientific secretary of St Thomas Aquinas Institute of Religious Sciences in Kyiv.

e-mail: rassudina.k@gmail.com

https://orcid.org/0000-0000-0001-6704-185X 